УДК 625.42

\title{
РОЗРАХУНОК ДЕРЕВ'ЯНОЇ ШПАЛИ В ТУНЕЛІ МЕТРОПОЛІТЕНУ НА МІЦНІСТЬ
}

Канд. техн. наук Д.А. Фаст

\section{РАСЧЕТ ДЕРЕВЯННОЙ ШПАЛЫ В ТОННЕЛЕ МЕТРОПОЛИТЕНА НА ПРОЧНОСТЬ}

Канд. техн. наук Д.А. Фаст

\section{STRENGTH CALCULATION OF WOODEN RAILROAD TIE IN THE TUNNEL OF UNDERGROUND}

Cand. of techn. sciences D.A. Fast

Досліджено напружено-деформований стан дерев'яної шпали в тунелі метрополітену, яка омонолічена в колійному бетоні. Для иього було використано відому методику розрахунку за Правилами розрахунків залізничної колї̈ на міиність $і$ стійкість. Складено модель $і$ розрахункову схему для залізничної колії в умовах експлуатації в тунелі метрополітену.

Ключові слова: дерев'яна шпала метрополітену, розрахунок, міџність, напруження, модуль пружності.

Исследовано напряженно-деформированное состояние деревянной шпаль в тоннеле метрополитена, омоноличенной в путевом бетоне. Для этого было использовано известную методику расчета согласно с "Правилами розрахунків залізничної колії на міцність і стійкість". Составлено модель и расчетную схему для железнодорожного пути в условиях эксплуатации в тоннеле метрополитена.

Ключевые слова: деревянная шпала метрополитена, расчет, прочность, напряжения, модуль упругости.

In this work investigational tensely deformed consisting of wooden railroad tie of tunnel of underground passage, what lies in a travel concrete. For this known technique has been used for calculating according to the "Rules of calculation of railway track for strength and stability". Compiled model and calculation scheme for railway tracks in operation in a tunnel underground. 
Under the influence of the rolling stock in the elements of permanent way appear tension and strain. The dependence of the forces that influence the track is complex and defies precise definition. Therefore, in the calculation of railway track in the subway tunnels are made on the strength of the preconditions according to the existing rules. modulus.

Keywords: wooden railroad tie of underground passage, calculation, strength, tensions, elastic

Вступ. У великих містах найбільш зручним і економічним видом пасажирського транспорту $\epsilon$ підземні залізниці, найважливішою перевагою яких $є$ велика швидкість перевезення і здатність освоювати масові пасажиропотоки. Очевидні переваги підземного громадського транспорту створюють передумови для його безперервного розвитку та удосконалення.

На магістральних ділянках залізниць основну частину дерев'яних шпал замінено залізобетонними. Вони мають більші терміни служби, забезпечують постійну ширину колії, менше зазнають атмосферних впливів i вимагають менших витрат на утримання. Але в умовах експлуатації в тунелях метрополітену, де баластом під рейко-шпальну решітку $\epsilon$ монолітна бетонна основа, використання залізобетонних шпал ускладнюється збільшеною жорсткістю основи. Тому для метрополітену найбільш ефективною $\epsilon$ конструкція колії на дерев'яних шпалах $[1,2]$.

Постановка проблеми у загальному вигляді та її зв'язок із важливими науковими та практичними завданнями. Особливо важливим завданням $є$ підвищення довговічності споруд i конструкцій метрополітену, забезпечення стійкої роботи колії та її елементів, відповідальних за безпеку та безперебійність руху поїздів, зниження витрат на поточне утримання та ремонт колії й тунельних споруд, що особливо актуально в умовах енерго- та ресурсозбереження в усіх галузях економіки держави. Розвиток i вдосконалення елементів верхньої будови колії пов'язані 3 появою нових матеріалів для їхнього виготовлення i спрямовані на забезпечення більш надійної конструкції колії, економію витрат на проміжні ремонти, зменшення енерго- і трудовитрат.

Основною відмінною рисою експлуатації дерев'яних шпал у метрополітені $\epsilon$ те, що вони утоплені в колійний бетон і у зв'язку з цим заміна їх новими $\epsilon$ досить складною й дорогою операцією, що вимагає значних витрат ручної праці й коштів. Для того щоб відновлювати їхні експлуатаційні властивості, необхідно розрахувати несучу здатність підрейкової основи з урахуванням iї неоднорідності, а саме дерев'яної шпали, що частково лежить на бетоні.

Аналіз останніх досліджень i публікацій. Останнім часом більше уваги приділяється дослідженню міцності залізничної колії на магістральних залізницях. Методика розрахунку несучої здатності існуючої конструкції колії на дерев'яних шпалах у тунелі метрополітену розглянуто недостатньо. В основному дослідження направлені на удосконалення зони проміжного скріплення, а також пошук нових конструкцій підрейкової основи $[1,2]$.

Визначення мети та задачі дослідження. Метою даних досліджень $\epsilon$ визначення несучої здатності суцільної дерев'яної шпали метрополітену 3 використанням методики розрахунку за Правилами розрахунків залізничної колії на міцність і стійкість. Завданнями досліджень $\epsilon$ визначення вертикального модуля пружності для підрейкової основи залізничної колії в метрополітені; визначення напруженодеформованого стану дерев'яної шпали, що частково лежить на колійному бетоні i порівняння $з$ допустимими значеннями.

Основна частина дослідження. В інженерній практиці часто зустрічаються балки, що лежать на суцільній пружній основі. До таких конструкцій належать шпали й рейки залізничної колії, стрічкові фундаменти будинків, що опираються на грунти, та ін.

Дерев'яні шпали в тунелі метрополітену частково омонолічені в колійний бетон, тому по довжині мають змінний коефіцієнт постелі $[3,4]$. Вони мають вигляд балки, що опирається на бетонну основу уздовж $2 / 3$ довжини шпали (рис. 1). 


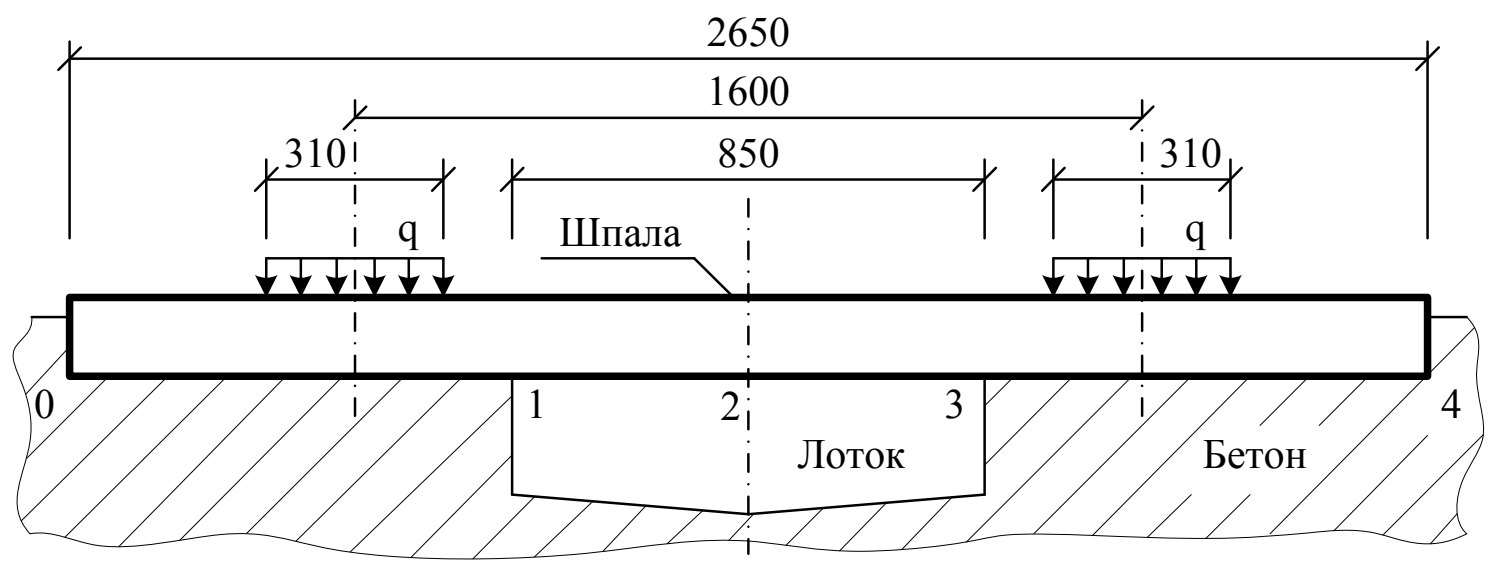

Рис. 1. Поздовжній розріз дерев'яної шпали в тунелі метрополітену

Розрахунок даної конструкції необхідно виконувати на міцність при роботі шпали на стиск за "Правилами розрахунків залізничної колії на міцність і стійкість" [5]. Теоретичними дослідженнями в цій галузі займалося багато вчених, серед яких професори B.I. Ангелейко, М.М. Біляєв, М.Ф. Веріго, В.М. Данілов, Е.І. Даніленко, В.В. Рибкін, О.П. Єршков, А.Я. Коган, М.А. Фрішман, Г.М. Шахунянц, В.Ф. Яковлєв, М.А. Чернишов, Л.В. Клименко [5-10].

Під дією рухомого складу в елементах верхньої будови колії виникають напруження та деформації. Залежність їх від сил, що впливають на колію, $є$ складною та не піддається точному визначенню. Тому в розрахунку залізничної колії в тунелі метрополітену на міцність приймаються передумови відповідно до існуючих Правил [5].

Для вирішення завдання з іiі розрахунку необхідно створити розрахункову схему та модель колії метрополітену, які показано на рис. 2.

Для визначення вертикальних сил, що діють на підрейкову підкладку проміжного рейкового скріплення типу "Метро", для наступного конструювання альтернативних конструкцій підрейкової основи замість заміни дерев'яних шпал (гнилих i трухлявих) необхідно підрахувати величину вертикального модуля пружності підрейкової основи $U$ безбаластної залізничної колії на дерев'яних шпалах у тунелі метрополітену.

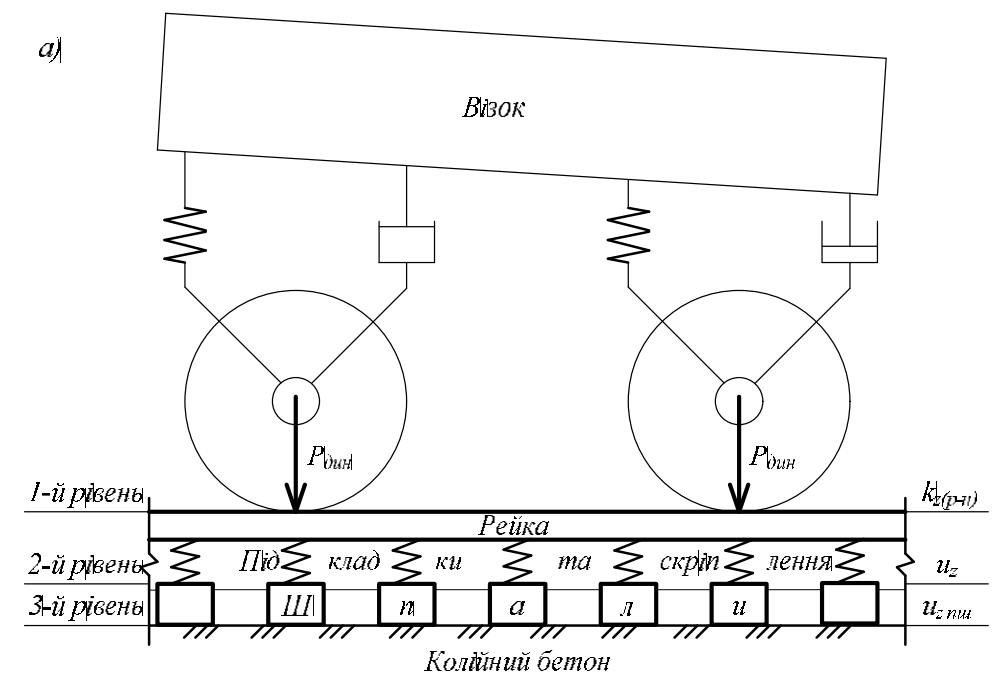

6)

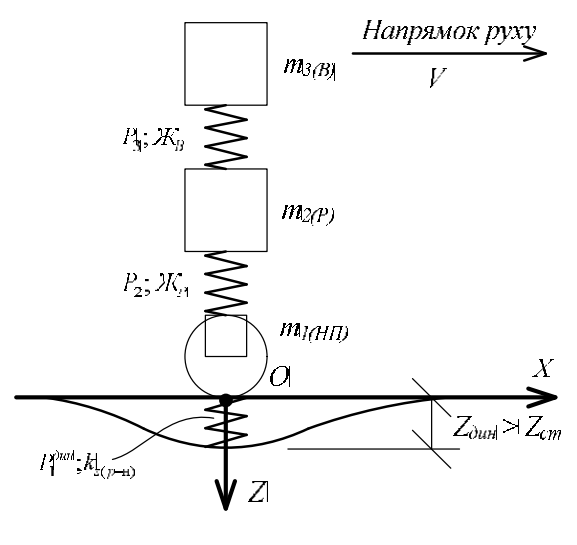

Рис. 2. Модель колії метрополітену для розрахунків на міцність (а) і розрахункова схема (б) 
Якщо розглянути одношарову конструкцію підрейкової основи, то на підставі закону Гука можна записати, що напруження, які виникають у матеріалі $\sigma_{i}, \epsilon$ пропорційними величині відносної деформації матеріалу $\varepsilon_{i}$

$$
\sigma_{i}=\varepsilon_{i} \cdot E_{i},
$$

де $E_{i}$ - модуль пружності матеріалу.

Відомо, що відносна деформація може бути визначена як відношення абсолютної деформації $y_{i}$ до початкового лінійного розміру матеріалу $h_{i}$

$$
\varepsilon_{i}=\frac{y_{i}}{h_{i}}
$$

Якщо об'єднати вирази (1) i (2), то одержимо таке:

$$
\sigma_{i}=\frac{y_{i}}{h_{i}} \cdot E_{i}
$$

Але відношення $E_{i} / h_{i}=C_{i}-$ коефіцієнт постелі матеріалу. Якщо матеріал або конструкція розглянутого матеріалу не мав певних пружних характеристик $E_{i}$, що знаходиться під дією сили Д, яка створює його деформацію $y=1 \mathrm{~cm}$, то можемо записати

$$
Д_{i}=C_{i} \cdot \omega_{i},
$$

де $\omega_{i}$ - площа обпирання конструкції.

За наявності декількох шарів $\mathrm{y}$ конструкції рейкового скріплення - дерев'яної прокладки, гумової прокладки i самої дерев'яної шпали - можна визначити загальну величину сили Д таким чином:

$$
\text { Д = } \frac{1}{\sum \frac{1}{Д_{i}}}=\frac{1}{\frac{h_{p n}}{\omega_{p n} \cdot E_{p n}}+\frac{h_{\partial n}}{\omega_{\partial n} \cdot E_{\partial n}}+\frac{h_{u}}{\omega_{u} \cdot E_{u}}},
$$

де $\omega_{\partial n}$ - площа дерев'яної прокладки, $\omega_{\partial n}=$ $=510 \mathrm{~cm}^{2}$;

$\omega_{p n}$ - площа підрейкової прокладки, $\omega_{p n}=$ $=210 \mathrm{~cm}^{2}$;

$\omega_{w}$ - площа опорної поверхні частини шпали, на яку поширюється навантаження, $\omega_{u}=2500 \mathrm{~cm}^{2}$;

$E_{p n}$ - модуль пружності гуми при стисканні, $E_{p n}=111 \kappa \Gamma / \mathrm{cm}^{2}$;
$E_{\partial n}$ - модуль пружності дерев'яної фанерної прокладки, $E_{\partial n}=27000$ кг $/ \mathrm{cm}^{2}$;

$E_{u}$ - модуль пружності деревини при стисканні поперек волокон, $E_{u}=5700$ кг $/ \mathrm{cm}^{2}$;

$h_{p n}$ - товщина гумової прокладки, $h_{p n}=$ $=0,5 \mathrm{~cm}$;

$h_{\partial n}-$ товщина дерев'яної прокладки, $h_{\partial n}=$ $=1 \mathrm{~cm}$;

$h_{u}$ - товщина дерев'яної шпали, $h_{u}=16$ см.

$$
Д=\frac{1}{\frac{0,5}{210 \cdot 111}+\frac{1}{510 \cdot 27000}+\frac{16}{2500 \cdot 5700}}=44159 \kappa 2 c / c \mathcal{M}=43305 \kappa H / \mu .
$$

Величина вертикального модуля пружності підрейкової основи безбаластної залізничної колії на дерев'яних шпалах у тунелі метрополітену без урахування пружних характеристик колійного бетону марки 150 i тунельного оброблення становить таку величину:

$$
U=\frac{Д}{L},
$$

де $L$ - відстань між осями сусідніх шпал у кривих ділянках колії при епюрі 1840 шт./км, $L=0,54$ м.

$$
U=\frac{43305}{0,54}=80194,5 \kappa \mathrm{H} / \mathrm{M}^{2} .
$$

Для визначення розрахункового навантаження на півшпалу використовуємо загальноприйняту методику розрахунку колії 


\section{Будівельні матеріали, конструкції та споруди}

на міцність від дії рухомого складу метрополітену. За відомих характеристик верхньої будови колії та параметрів рухомого складу метрополітену було виконано необхідні розрахунки для визначення максимальноймовірного динамічного тиску колеса на головку рейки та нормальних напружень, що виникають на шпалі.

Розрахункові нормальні напруження під підкладкою визначаються за формулою

$$
\sigma_{u}=\frac{Q}{\omega_{n}}
$$

де $\omega_{n}$ - площа підкладки, $\omega_{n}=0,0496 \mathrm{~m}^{2}$.

$$
\sigma_{u}=\frac{43}{0,0496}=867 \kappa \mathrm{H} / \mathrm{M}^{2}<\left[\sigma_{u}\right]=2200 \kappa \mathrm{H} / \mathrm{M}^{2}
$$

Висновки 3 дослідження. Аналізуючи отримані результати за допомогою методики, яка наведена у "Правилах розрахунків залізничної колії на міцність і стійкість”, можна зробити висновок, що дерев'яні шпали в тунелі метрополітену мають великий запас міцності в даних експлуатаційних умовах.

\section{Список використаних джерел}

1. Кравченко, Н.Д. Новые конструкции железнодорожного пути для метрополитенов [Текст] / Н.Д. Кравченко. - М.: Транспорт, 1994. - 143 с.

2. Замуховский, А.В. Шпалы-коротыши в путевом бетоне [Текст] / А.В. Замуховский // Путь и путевое хозяйство. - 2006. - № 5. - С. 24-26.

3. Красюк, А.Г. Расчет балок на сплошном упругом основании со ступенчатым изменением жесткости [Текст] / А.Г. Красюк // Залізничний транспорт України. - 2003. - № 5. - С. 12-14.

4. Клименко, Л.В. Расчет пути с учетом неравноупругости подрельсового основания [Текст] / Л.В. Клименко // Путь и путевое хозяйство. - 2007. - № 9. - С. 34-35.

5. Правила розрахунків залізничної колії на міцність і стійкість [Текст] / Е.І. Даніленко, В.В. Рибкін. - К.: Транспорт України, 2006. - 168 с.

6. Даніленко, Е.І. Залізнична колія. Улаштування, проектування і розрахунки, взаємодія 3 рухомим складом [Текст]: підруч. [для студ. вищ. навч. закл.] в 2 т. / Е.І. Даніленко. - К.: Інпрес, 2010. - T. 2. $-456 \mathrm{c}$.

7. Вериго, М.Ф. Взаимодействие пути и подвижного состава [Текст] / М.Ф. Вериго, А.Я. Коган. - М. : Транспорт, 1986. - 559 с.

8. Альбрехт, В.Г. Основы устройства и расчетов железнодорожного пути [Текст] / В.Г. Альбрехт, М.П. Смирнов, В.Я. Шульга [и др.]; под ред. С.В. Амелина и Т.Г. Яковлевой. - М.: Транспорт, 1990. - 367 с.

9. Kaewunruen, S. Dynamic Properties of Railway Track and Its Components: A State-of-the-Art Review [Електронний ресурс] / S. Kaewunruen, A.M. Remennikov // New Research on Acoustics. - 2008. - C. 197-220. - Режим доступу: https://books.google.com.ua/books?id=J6skxo31EVIC\&pg =PA197\&dq $=\mathrm{kaewunruen} \& \mathrm{hl}=\mathrm{ru} \# \mathrm{v}=$ onepage $\& \mathrm{q}=\mathrm{kaewunruen} \& \mathrm{f}=$ false.

Рецензент д-р техн. наук, професор О.М. Даренський

Фаст Денис Андрійович, кандидат технічних наук, доцент кафедри колії та колійного господарства, Український державний університет залізничного транспорту. Тел.: (057) 730-10-59. E-mail: denia007@mail.ru.

Fast Denis Andreevich, candidate of technical sciences associate professor of «Track and track facilities» Ukrainian State University of Railway Transport. Phone: (057) 730-10-59. E-mail: denia007@mail.ru.

Стаття прийнята 21.09.2015 p. 